Клинкова Е. В.

E. V. Klinkova

МЕЖДУНАРОДНЫЕ ЛИНГВИСТИЧЕСКИЕ МЕРОПРИЯТИЯ

КОМСОМОЛЬСКОГО-НА-АМУРЕ ГОСУДАРСТВЕННОГО ТЕХНИЧЕСКОГО

УНИВЕРСИТЕТА 2015-2016

\title{
INTERNATIONAL LINGUISTICS EVENTS OF KOMSOMOLSK-ON-AMUR STATE TECHNICAL UNIVERSITY (2015-2016)
}

Клинкова Екатерина Викторовна - старший преподаватель кафедры иностранные языки гуманитарного факультета Комсомольского-на-Амуре государственного технического университета (Россия, Комсомольск-на-Амуре). E-mail: katekl@mail.ru.

Ms. Ekaterina V. Klinkova - Senior Lecturer, Foreign Languages Department, Faculty of Humanities, Komsomolsk-on-Amur State Technical University (Russia, Komsomolsk-on-Amur). E-mail: katekl@mail.ru.

УДК $81: 378$

В период с 16 декабря 2015 г. по 13 апреля 2016 г. в Комсомольском-на-Амуре государственном техническом университете проводились мероприятия в рамках реализации Плана сетевых (кластерных) профильных мероприятий КнАГТУ и отдела образования администрации г. Комсомольска-на-Амуре на 2015-2016 учебный год. В конкурсах, олимпиадах и конференциях принимали участие учащиеся старших классов средних школ города и лицея КнАГТУ, студенты первых и вторых курсов неязыковых специальностей и направлений КнАГТУ и АмГПГУ, в том числе иностранные граждане (КНР и Республика Мьянма). Организатором конкурсов выступила кафедра «Иностранные языки».

16 декабря 2015 г. состоялся «Международный фонетический конкурс» на английском языке. Конкурс проводился как в очной форме, так и дистанционной, в два этапа. На первом этапе каждому участнику раздавался текст для выразительного чтения. Второй этап конкурса считался творческим. Участники рассказывали любимые поэтические произведения на английском языке. Участники дистанционной формы проведения конкурса записывали свои выступления на видео и присылали в оргкомитет в день проведения конкурса на электронную почту. Отрывок для чтения был выбран из книги Оскара Уайльда «Портрет Дориана Грея». В конкурсе приняли участие 20 студентов неязыковых специальностей КнАГТУ, 7 учащихся старших классов средних школ города Комсомольска-на-Амуре и 5 иностранных студентов КнАГТУ (КНР и Республика Мьянма). По итогам конкурса все участники были номинированы и награждены памятными призами и грамотами. Среди номинаций были: «Артистизм и перфекционизм», «Оригинальность и мастерство исполнения», «Выразительность», «Современное прочтение Шекспира», «Импровизация».

10 февраля 2016 г. проходил Международный лингвострановедческий конкурс «Лингвоэрудит» на английском языке. Конкурс состоял из двух заданий: лингвострановедческий тест и эссе на тему «Что такое английский характер?». В конкурсе приняли участие 25 студентов технических специальностей КнАГТУ и 10 учащихся старших классов средних школ города Комсомольска-на-Амуре. В ходе подведения итогов активным участникам были присуждены следующие номинации: «Аудирование», «Страноведение», «Эссе», «Гран-при». Победителями конкурса стали студенты технических специальностей КнАГТУ: Куликов Алексей, гр. 5ИБб-1, занявший первое место; Ефимов Алексей, гр. 4ИНб-1, занявший второе место; Евтушенко Данил, гр. 4МАб-1, занявший третье место. 
3 марта 2016 г. стартовала международная олимпиада «Английский язык в мировом сообществе». В олимпиаде приняло участие 30 студентов технических специальностей КнАГТУ, 8 учащихся старших классов средних школ города Комсомольска-на-Амуре и 8 иностранных студентов КнАГТУ (КНР и Республика Мьянма). Олимпиада проводилась в два этапа, первый этап включал в себя: аудирование; задание на нахождение и исправление ошибок в деловом письме; задание па восстановление реплик диалога из заданных слов; письменный (литературный) перевод текста аннотации с английского языка на русский (со словарем), объем - 800 печатных знаков, средняя степень сложности. Среди участников олимпиады выявлялись лучшие в количестве 10 человек, которые получали право участвовать во втором этапе. Второй этап проводился с 10 по 31 марта 2016 г. в дистанционной форме. Второй этап носил творческий характер и предполагал написание эссе на тему «Английский язык в мире и в моей жизни». Для участия во втором этапе олимпиады участникам необходимо было направить эссе на заданную тему на указанный в письме электронный адрес. По итогам олимпиады активным участникам были присуждены следующие номинации: «Аудирование», «Диалогическая речь», «Перевод аннотации», «Редактирование делового письма», «Лучшее эссе». Победителями олимпиады стали: студентка КнАГТУ гр. 5ПЭб-1 Ненюк Вероника и Капустина Полина учащаяся 11 класса МОУ СОШ № 27 г. Комсомольска-наАмуре, разделившие первое место; студенты КнАГТУ гр. 5ХТб-1 Ежак Илья и Боровикова Софья заняли второе место; третье место заняла Ковко Ирина учащаяся 11 класса МОУ СОШ № 51 г. Комсомольска-на-Амуре.

Заключительным мероприятием была Открытая международная конференция по английскому языку «Мое место в современном обществе», которая проводилась 13 апреля 2016 г. К участию приглашались студенты 1-2 курсов неязыковых направлений высших учебных заведений, учащиеся 10-11 классов общеобразовательных средних школ и лицеев, а также учащиеся образовательных учреждений среднего профессионального образования Хабаровского края. В конкурсе приняли участие 15 студентов неязыковых специальностей КнАГТУ, 5 учащихся старших классов средних школ города Комсомольска-на-Амуре и 4 иностранных студента КнАГТУ (КНР и Республика Мьянма). Доклады составлялись на английском языке по теме конференции и должны были сопровождаться презентацией. Сообщение каждого из участников должно было занимать не более 5 минут. В ходе подведения итогов каждый участник получил памятный приз и грамоту.

В заключении хочется добавить, что проведение мероприятий с привлечением учащихся средних и высших учебных заведений и иностранных студентов стало традицией на кафедре «Иностранные языки». Как показала практика, ежегодные студенческие конкурсы, конференции и олимпиады с каждым разом приобретают все большую масштабность, а участие в данных мероприятиях уже стало позитивной лингвистической традицией университета. 